\title{
FACEBOOK OVERSIGHT BOARD'S DECISION ON THE INDEFINITE SUSPENSION OF DONALD TRUMP'S ACCOUNT
}

\begin{abstract}
On May 5, 2021 Facebook Oversight Board, a global body created by the company to act as an independent appeals mechanism for Facebook's content moderation, issued its highly awaited decision concerning the "indefinite suspension" of former US President Donald Trump's account. The suspension was originally imposed by Facebook between January 6 and 7, 2021 for Trump's posts related to the attacks on Capitol Hill in Washington, DC. This case note shows the Oversight Board's almost exclusive reliance on international human rights standards in deciding the case. It sees it as a positive development. Additionally, the author argues that the decision also highlights Facebook's struggle and potential lack of willingness to develop a unified approach to its treatment of political leaders and the company's reluctance to grapple with the way its business model has potentially contributed to violent events, including the attacks on the Capitol Hill on January 6, 2021.
\end{abstract}

Key words: Facebook, Oversight Board, Donald Trump, freedom of expression, social media, content moderation, indefinite suspension, political leaders, high-profile accounts, international human rights law.

The Facebook Oversight Board (FOB) is a global body created by Facebook and envisioned as an independent ${ }^{1}$ appeals mechanism for Facebook's content moderation decisions. ${ }^{2}$ It began operating in October

* Associate, Mikijelj Janković Bogdanović; Teaching Assistant, Union University Law School Belgrade; LL.M. (Leiden); e-mail: ivana.vukcevic@mjb.rs

1 It is funded by Facebook, but the funds are removed from Facebook's direct control through a trust. Harris, B. An Update on Building a Global Oversight Board, 2019, Facebook Newsroom, (https://about.fb.com/news/2019/12/oversight-board-update/, 30. 5. 2021); Oversight Board Trust Agreement, 2019, (https://about.fb.com/ wp-content/uploads/2019/12/Trust-Agreement.pdf, 30. 5. 2021); Limited Liability Company Agreement of Oversight Board LLC, 2019, (https://about.fb.com/wp-content/uploads/2019/12/LLC-Agreement.pdf, 30. 5. 2021); Deed of Amendment, 2020, (https://about.fb.com/wp-content/uploads/2020/10/Oversight-Board-Third-Deedof-Amendment-Fully-Executed-with-Conformed-Trust11.pdf, 30. 5. 2021).

2 Oversight Board Charter, 2019, (https://about.fb.com/wp-content/uploads/2019/09/oversight_board_charter.pdf, 30.5. 2021). 
$2020^{3}$ and it is governed by the Oversight Board Charter ${ }^{4}$ and the bylaws. ${ }^{5}$ On May 5, 2021, FOB issued its decision on the 'indefinite suspension' of former US President Donald Trump's Facebook account. ${ }^{6}$ This is so far the most high-profile decision to come out of Facebook's self-regulatory experiment and, considering its subject matter, it was always bound to generate a fair share of commentary. However, beyond the question whether Donald Trump will be returning to the platform or not, the FOB's decision is significant for highlighting Facebook's continuing struggle (and perhaps lack of willingness) to develop a unified approach to its treatment of political leaders and the company's reluctance to grapple with the way its business model has potentially contributed to violent events, including the attacks on the Capitol Hill in Washington DC on January 6, 2021.

\section{Factual Background and the Oversight BOARD'S DECISION}

The FOB assessed Facebook's decision to suspend Mr. Trump's account under three categories: Facebook's Community Standards, Facebook's Values, and international human rights law. ${ }^{7}$

3 Ghaffary, S., 2020, Facebook's independent oversight board is finally up and running, Vox Recode, (https://www.vox.com/recode/2020/10/22/21528859/facebook-oversight-board-mark-zuckerberg; 30. 5. 2021). First 20 members of the Oversight Board were appointed by Facebook in May 2020, and they are supposed to name the rest of the Board's members to the full capacity of 40 members. (https://www.oversightboard.com/news/announcing-the-first-members-of-the-oversight-board/).

4 Oversight Board Charter, 2019, (https://about.fb.com/wp-content/uploads/2019/09/oversight_board_charter.pdf, 30. 5. 2021).

5 Oversight Board Bylaws, 2020, (https://oversightboard.com/sr/governance/bylaws, 30. 5. 2021); Facebook has unlimited opportunity to refer cases to the OB, while users have this opportunity to only in cases related to specific pieces of content posted on Facebook or Instagram. The Board itself choses if it will review the case. Board's decisions are prepared by panels of five members and then approved by the majority of the Board. See Oversight Board Charter and Bylaws Oversight Board website, (https:// oversightboard.com/appeals-process/, 30. 5. 2021); Oversight Board website, update on the appeals procedure, (https://oversightboard.com/news/267806285017646-theoversight-board-is-accepting-user-appeals-to-remove-content-from-facebook-andinstagram/, 30. 5. 2021).

6 Case Decision 2021-001-FB-FBR. At https://www.oversightboard.com/decision/ FB-691QAMHJ/Facebook Oversight Board, May 5, 2021.

7 Facebook Oversight Board, Case Decision 2021-001-FB-FBR, 5 May 2021, (https:// www.oversightboard.com/decision/FB-691QAMHJ/, 27. 5. 2021) (“Oversight Board Decision on Donald Trump's Suspension"). 
The review focuses on two posts made by Donald Trump on January 6, 2021 ${ }^{8}$ : (1) a video posted on his Facebook and Instagram account in which he addressed the participants of the attack on the Capitol Hill in Washington DC, ${ }^{9}$ urging them to go home but also repeating unfounded allegations of election fraud that prompted the attack and telling the rioters: "We love you. You're very special"; and (2) a written post on his Facebook account stating: "These are the things and events that happen when a sacred landslide election victory is so unceremoniously \& viciously stripped away from great patriots who have been badly \& unfairly treated for so long. Go home with love \& in peace. Remember this day forever!"

Facebook removed both posts on the same day, and it imposed a 24hour suspension on Mr. Trump's account. Upon further review, on January 7, 2021, Facebook extended the suspension "indefinitely and for at least the next two weeks until the peaceful transition of power is complete". ${ }^{10}$ Facebook then referred the case to FOB and asked it to answer two questions:

Considering Facebook's values, specifically its commitment to voice and safety, did it correctly decide on January 7, 2021, to prohibit Donald J. Trump's access to posting content on Facebook and Instagram for an indefinite amount of time?

In addition to the board's determination on whether to uphold or overturn the indefinite suspension, Facebook welcomes observations or recommendations from the board about suspensions when the user is a political leader. ${ }^{11}$

In reviewing Facebook's decision under its content policies, the FOB agreed that Mr. Trump's posts violated Facebook's Dangerous Individuals and Organizations Community Standard, ${ }^{12}$ which prohibits content "expressing support or praise for groups, leaders, or individuals involved in" activities that entail violence ("violating event"). Such policy also includes events Facebook designates as violent. The FOB came to this conclusion

8 The Decision refers to these posts as „two pieces of content“. See Oversight Board Decision on Donald Trump's Suspension, pp. 1-2.

9 See e.g. Tan, S., Shin, Y., Rindler, D., 2021, How one of America's ugliest days unravelled inside and outside the Capitol, Washington Post, (https://www.washingtonpost. com/nation/interactive/2021/capitol-insurrection-visual-timeline/, 26. 5. 2021).

10 Oversight Board Decision on Donald Trump's Suspension, pp. 1-2, 10-11. See also Mark Zuckerberg's announcement on his Facebook account, (https://www.facebook. com/zuck/posts/10112681480907401, 27. 5. 2021).

11 Oversight Board Decision on Donald Trump's Suspension, p. 8.

12 Facebook Community Standards on Dangerous Individuals and Organizations, (https://www.facebook.com/communitystandards/dangerous_individuals_organizations, 30. 5. 2021). 
because Facebook had designated the Capitol Hill attack as a "violent event" and Mr. Trump's comments - "We love you. You're very special" in the first post and "great patriots" and "Remember this day forever" in the second - amounted to praise or support of the event and individuals involved. ${ }^{13}$ The FOB also found that restricting Mr. Trump's account (at least on 6 and 7 January) was consistent with Facebook's values ${ }^{14}$ of "Voice" and "Safety", with concerns over the protection of public order outweighing the interest in preserving freedom of speech in this case. ${ }^{15}$

The FOB reached its decision by focusing on Facebook's human rights responsibilities as a company. It relied on UN Guiding Principles on Business and Human Rights ${ }^{16}$ endorsed by Facebook, and international human rights instruments including the International Covenant on Civil and Political Rights (ICCPR), ${ }^{17}$ General Comment no. $34,{ }^{18}$ the Rabat Plan of Action ${ }^{19}$ and the 2018 UN Special Rapporteur on freedom of opinion and expression report. ${ }^{20}$ In other words, the FOB reviewed Facebook's decision by applying the well-established three-part test of legality, purpose, and proportionality. ${ }^{21}$

The principle of legality requires that a decision shall be made pursuant to a clear and accessible rule. ${ }^{22}$ The FOB found that the Dangerous

13 Oversight Board Decision on Donald Trump's Suspension, pp. 23-24.

14 Facebook's values are expressed in the Introduction to its Community Standards, (https://www.facebook.com/communitystandards/introduction, 30. 5. 2021).

15 Oversight Board Decision on Donald Trump's Suspension, pp. 24-25.

16 UN Office of the High Commissioner for Human Rights, Guiding Principles on Business and Human Rights: Implementing the United Nations "Protect, Respect and Remedy" Framework, UN doc. HR/PUB/11/4 (2011).

17 International Covenant on Civil and Political Rights, adopted 16 December 1966, entered into force 23 March 1976, 999 UNTS 171, (“ICCPR").

18 Human Rights Committee, General Comment No. 34, UN doc. CCPR/C/GC/34 (12 September 2011) (“General Comment No. 34").

19 Human Rights Council, Rabat Plan of Action on the prohibition of advocacy of national, racial or religious hatred that constitutes incitement to discrimination, hostility or violence, UN doc. A/HRC/22/17/Add.4 (11 January 2013).

20 Human Rights Council, Report of the Special Rapporteur on the promotion and protection of the right to freedom of opinion and expression, $\mathrm{UN}$ doc. A/HRC/38/35 (6 April 2018).

21 Oversight Board Decision on Donald Trump's Suspension, pp. 15-16, 26. The Board primarily relied on Articles 19 and 20 of the ICCPR and the other listed documents, but it also took into account Articles 2, 6, 9(1), 25 and 26 of the ICCPR and Articles 1 and 4 of the International Convention on the Elimination of All Forms of Racial Discrimination, adopted 21 December 1965, entered into force 4 January 1969, 660 UNTS 195. On this see more in Schabas, W. A., 2019, Nowak's CCPR Commentary: U.N. International Covenant on Civil and Political Rights, 3rd rev. ed., Kehl, N. P. Engel Publisher. Oversight Board Decision on Donald Trump's Suspension, p. 27. 
Individuals and Organizations Community Standard was sufficiently clear, in the circumstances of the concrete case, ${ }^{23}$ to give notice that $\mathrm{Mr}$. Trump's posts were violations. However, the FOB criticized Facebook's "patchwork of applicable rules" on penalties and found that the penalty Facebook imposed on Mr. Trump did not meet the standard of legality. Namely, neither Facebook's Community Standards, its Terms of Service, nor other public pronouncements by the company provided indefinite suspension as a possible consequence of policy violations, nor was it clear what standards would trigger such penalty or apply to it. ${ }^{24}$

The FOB found the other two requirements of the three-part test legitimate aim and proportionality - were met. Namely, in the FOB's view, Facebook's policy on praising and supporting individuals involved in "violating events" restricted freedom of expression in accordance with the legitimate aim of protecting "public order, as well as respect for the rights of others, including the rights to life, security, and to participate in elections and to have the outcome respected and implemented". ${ }^{25}$

Under the requirement of necessity and proportionality, any restriction imposed on free speech must be accomplished by the least restrictive means to achieve the legitimate aim. ${ }^{26}$ The FOB found that it would be difficult to assess whether less severe measures, taken earlier, would have been more appropriate because Facebook declined to clarify "the extent to which the platform's design decisions, including algorithms, policies, procedures and technical features, amplified Mr. Trump's posts after the election and whether Facebook had conducted any internal analysis of whether such design decisions may have contributed to the events of January $6 "{ }^{27}$

The FOB also emphasized that the crucial issue is whether the restrictions applied to Mr. Trump's account were necessary and proportionate to protect the rights of others. To that end, the FOB analysed Mr. Trump's posts and off-platform comments since the November 2020 US presidential elections and found that even though his January 6 posts included a "seemingly perfunctory call for people to act peacefully", they supported the rioters and legitimized their actions. ${ }^{28}$

23 The board has, however, expressed concerns about the clarity of the Dangerous Individuals and Organizations Community Standard in different circumstances. See Facebook Oversight Board, Case Decision 2021-005-FB-UA, 28 January 2021.

24 Oversight Board Decision on Donald Trump's Suspension, pp. 27-28.

25 Ibid., p. 28. See also Article 19(3) of the ICCPR, and General Comment No. 34, on which the Decision relies in establishing what represents legitimate aim.

26 Ibid., p. 29. See also General Comment No. 34, para. 34.

27 Ibid., p. 29.

28 Ibid., pp. 29-30. 
Drawing upon the factors set out in the Rabat Plan of Action ${ }^{29}-\mathrm{a}$ result of the UN Office of the High Commissioner for Human Rights initiative clarifying the scope of obligations under the prohibition of hate speech from Article 20 of the ICCPR, which provides a six-part test for assessment of incitement of hatred cases ${ }^{30}$ - the FOB concluded (1) that the posts were made at the time of high political tension centred around the Trump campaign's unfounded claim of election fraud; (2) that Mr. Trump as then-current President of the US had a high degree of influence; (3) that Mr. Trump likely knew or should have known that his statements would pose a risk of legitimizing or encouraging violence; (4) that the content of the statements ultimately legitimized and supported the rioters; (5) that the size of Mr. Trump's following on Facebook and Instagram significantly increased his reach; and, (6) that because the posts were made during a "dynamic and fluid period of ongoing violence" there was an imminent and clear risk of harm. ${ }^{31}$ Based on these conclusions, the FOB found that Facebook's imposition of restrictions on Mr. Trump's account on 6 and 7 January 2021 met necessity and proportionality requirements.

Finally, and most importantly, the FOB directed Facebook to revisit the suspension of Mr. Trump's account and impose a penalty that is based on the gravity of the violation and the prospect of future harm and consistent with Facebook's rules for severe violations. The FOB gave Facebook six months to issue a new penalty. It also criticized Facebook for seeking to avoid responsibility when it applied a vague, standardless penalty and then referred the case to the FOB. ${ }^{32}$

Additionally, the FOB issued a relatively long list of policy recommendations ("policy advisory statements") to Facebook that are non-binding, ${ }^{33}$ including recommendations on the question specifically put forward by Facebook regarding the suspension of political leaders. Generally, these recommendations can be classified in five broader categories.

29 Human Rights Council, 2013. In its submission, Facebook itself also states that it relied on the Rabat Plan of Action when making the decision to impose restrictions on Mr. Trump's account. See Oversight Board Decision on Donald Trump's Suspension, pp. $20-21$.

30 Human Rights Council, 2013, p. 11, para. 29.

31 Oversight Board Decision on Donald Trump's Suspension, pp. 30-31.

32 Ibid., p. 33.

33 Article 2 Section 4 of the Oversight Board Charter provides that the final decision, at the board's discretion, may include policy advisory statements in addition to the determination on content. While Facebook will commit to the board's independent oversight on content decisions and the implementation of those decisions (Article 5 Section 3 of the Oversight Board Charter), no such obligation exists with respect to the policy advisory statements. 
First, the FOB suggested that a firm distinction between political leaders and other influential users is not always useful. ${ }^{34}$ Facebook should consider context "when assessing issues of causality and the probability and imminence of harm" related to the posts of such users. ${ }^{35}$ Nevertheless, in the FOB's view, if a head of state or high government official repeatedly posts messages that pose a risk of harm under international human rights norms, Facebook should suspend the account for a determined period, or, depending on the context, even consider deletion of the account or page. ${ }^{36}$ Second, the FOB recommended that when Facebook "imposes a time-limited suspension on account of an influential user to reduce the risk of significant harm", it should not reinstate the account until the risk has abated, implying a forward-looking harm assessment. ${ }^{37}$ Third, the FOB also recommended that Facebook "must resist pressure from governments to silence their political opposition" and that when assessing political risk, Facebook should be cautious to consider the political context. ${ }^{38}$ This requires specialized moderation staff that is familiar with the linguistic and political context and insulated from political and economic undue influence. ${ }^{39}$

Fourth, the FOB recommended that when Facebook implements special procedures that apply to influential users, these should be well documented. The FOB notes that in the case of Mr. Trump, it was not clear whether Facebook applied different standards as opposed to regular users, and many third-party submissions raised concerns over the potential application of the newsworthiness allowance. ${ }^{40}$ In response to the FOB's questions, Facebook expressly refuted the application of newsworthiness in Mr. Trump's case and denied having a general rule that was more permissive for content posted by political leaders. Instead, Facebook explained that it applies a "cross-check" system in cases of some influential users to minimize errors in the enforcement of its rules. ${ }^{41}$ In the light of this, the FOB recommended that Facebook

[p]roduce more information to help users understand and evaluate the process and criteria for applying the newsworthiness allowance, including how it applies to influential accounts. The company should also clearly

\footnotetext{
34 Oversight Board Decision on Donald Trump's Suspension, p. 33.

35 Ibid., p. 35.

36 Ibid., pp. 35-36.

37 Ibid., p. 36. A minority of the board believed that this should have been included in the binding part of the decision. Oversight Board Decision on Donald Trump's Suspension, pp. 33-34.

38 Ibid., p. 36.

39 Ibid.

40 Ibid.

41 Ibid., p. 12.
} 
explain the rationale, standards and processes of the cross check review, and report on the relative error rates of determinations made through cross check compared with ordinary enforcement procedures. ${ }^{42}$

Fifth, in view of the events of January 6, 2021, the FOB recommended that:

Facebook should undertake a comprehensive review of its potential contribution to the narrative of electoral fraud and the exacerbated tensions that culminated in the violence [...]. This should be an open reflection on the design and policy choices that Facebook has made that may enable its platform to be abused. Facebook should carry out this due diligence, implement a plan to act upon its findings, and communicate openly about how it addresses adverse human rights impacts it was involved with. ${ }^{43}$

Facebook must respond to the non-binding policy recommendations offered throughout the decision within 30 days. To the date of writing this case note, Facebook has not put out any public response to the FOB's recommendations.

Finally, it should be noted that the FOB posed a number of questions to Facebook that Facebook declined to reply. These included questions about how Facebook's news feed and other features impacted the visibility of Mr. Trump's content; whether Facebook has researched, or plans to research, those design decisions in relation to the events of January 6 , 2021; information about violating content from followers of Mr. Trump's accounts; information related to the suspension of other political figures and removal of other content; whether Facebook had been contacted by political officeholders or their staff about the suspension of Mr. Trump's accounts; and whether account suspension or deletion impacts the ability of advertisers to target the accounts of followers. ${ }^{44}$

\section{Commentary on the Oversight BOARD'S DECISION}

The two main issues raised by the decision relate to (1) the FOB's almost exclusive reliance on international human rights standards, and (2) questions of transparency and arbitrariness in Facebook's decision-making process in content moderation, and especially related to its approach to the high-profile accounts of political leaders. I will address them in turn.

42 Ibid., pp. 36-37. See also ibid., p. 6.

43 Ibid., p. 37.

44 Ibid., p. 21. 


\subsection{INTERNATIONAL HUMAN RIGHTS LAW}

References to human rights are scattered throughout the FOB's governance documents. The Oversight Board Charter provides that "[w]hen reviewing decisions, the FOB will pay particular attention to the impact of removing content in light of human rights norms protecting free expression." 45 Under the bylaws Facebook's response to FOB decisions should "be guided by relevant human rights principles" and the FOB's annual report should include, at minimum, an "analysis of how the FOB's decisions have considered or tracked the international human rights implicated by a case." ${ }^{46}$ Nevertheless, it is a significant development that international human rights law takes the spotlight in the FOB's decision. While the FOB reviews Facebook's restrictions on Mr. Trump's account in light of its community policy and its values, most of the FOB's analysis is based on international human rights standards ${ }^{47}$ and the application of the three-part test. The FOB explains this by reference to Facebook's commitment to the UN Guiding Principles on Business and Human Rights and Facebook's adoption of a corporate human rights policy. ${ }^{48}$

The FOB's reliance on international human rights law is the right approach. Despite the challenges that arise from applying a set of solutions developed for states to a purely private context, no other body of rules is more adequate to assess issues related to freedom of expression which transcend national and regional legal systems. ${ }^{49}$ Namely, social media platforms also have a societal role that goes beyond the purely private sphere, frequently becoming spaces of societal discourse with implications on political life, social well-being and public order. ${ }^{50}$ This gives these

45 Article 2 Section 2 of the Oversight Board Charter.

46 Article 1 Section 4.1 and Article 2 Section 2.3.2 of the Oversight Board Bylaws.

47 The board primarily relies on Articles 19 \& 20 of the ICCPR as interpreted in the General Comment no. 34, HRC (2011); the Rabat Plan of Action; 2018 UN Special Rapporteur on freedom of opinion and expression report. See above fns. 15-20. See also Oversight Board Decision on Donald Trump's Suspension, pp. 15-16.

48 Oversight Board Decision on Donald Trump's Suspension, p. 15. See also Facebook's Corporate Human Rights Policy, (https://about.fb.com/wp-content/uploads/2021/03/ Facebooks-Corporate-Human-Rights-Policy.pdf, 27. 5. 2021).

49 See Karanicolas, M., 2020, Squaring the Circle Between Freedom of Expression and Platform Law, Journal of Technology Law \& Policy, Vol. 20, p. 198; Milanovic, M., 2021, The Facebook Oversight Board Made the Right Call on the Trump Suspension, (https://www.ejiltalk.org/the-facebook-oversight-board-made-the-right-call-on-thetrump-suspension/, 25. 5. 2021).

50 Benesch, S., 2020, But Facebook's Not a Country: How to Interpret Human Rights Law for Social Media Companies, Yale Journal on Regulation Online Bulletin, pp. 92-95. 
companies a quasi-governing role, having the power to decide what people can say, but also see or hear. As Marko Milanovic notes, applying international human rights standards "becomes more appropriate the more a corporate actor has a monopolistic, quasi-regulatory position in a certain sphere of life, and Facebook certainly qualifies in that department."51

Moreover, international human rights law is conceptualized as a framework for assessing free speech in a way that supports a broad range of diverse and potentially conflicting viewpoints. It also provides a structured approach to assessing restrictions on harmful content through the three-part test. Though its requirements of legality, legitimate aim, necessity and proportionality cannot be transplanted onto the social media context without adjustments, ${ }^{52}$ it provides these companies with a normative framework for content moderation that integrates both the values of free speech and protection against harm. As a baseline for content moderation, it retains a degree of flexibility but has the potential to aid these enforcement mechanisms in achieving more transparency and predictability which is often an issue.

The circumstances of the case were not a challenge from the standpoint of the application of international human rights standards. The FOB had no difficulty in assessing the content of Mr. Trump's posts and finding that Facebook was justified in restricting his account. It was equally straightforward for the FOB to determine that the imposed "indefinite suspension" was arbitrary considering that it was not provided for in any of Facebook's policy documents or pronouncements, nor implemented before, and overall lacked clear criteria for its imposition.

\subsection{TRANSPARENCY AND ARBITRARINESS}

\section{IN THE CONTEXT OF A HIGH PROFILE POLITICAL DEBATE}

The decision also raises interesting issues regarding Facebook's treatment of accounts of political leaders, which relate to transparency. It focuses on a limited number of Mr. Trump's posts, i.e., only the two posts he made on January 6, 2021.

Such approach may be the consequence of the FOB's preferred narrow construction of the question posed by Facebook (which was opposed

51 Milanovic, M., 2021.

52 A detailed analysis of these issues is beyond the scope of this case note, but for considerations on the topic see e.g. Karanicolas, M., 2020, pp. 201-210; Benesch, S., 2020, pp. 102-110; Lwin, M., 2020, Applying International Human Rights Law for Use by Facebook, Yale Journal on Regulation Online Bulletin. 
by a minority of the FOB) ${ }^{53}$ However, it could also be the consequence of Facebook's refusal to clarify how newsfeed and other design features impacted the visibility of Mr. Trump's content or how it makes similar decisions about other political leaders. ${ }^{54}$ Namely, this could be taken to hinder the $\mathrm{OB}$ in more expansive reading of the question, which would allow the interpretation of standards for incitement, encouragement or endorsement of mass violence by political leaders.

The FOB does not provide any binding rules on how Facebook should handle incitement to violence by a political leader in view of its policy and values. ${ }^{55}$ However, such considerations of the FOB are contained in the non-binding policy recommendations, which clearly show that international human rights norms should guide such decisions. Namely, the FOB, in its recommendations reflects the need to consider the probability and imminence of harm and the status of the speaker as a political leader which is generally in line with international human rights standards. ${ }^{56}$

The decision overall points to a level of arbitrariness that is present in the way Facebook treats accounts of high-profile users, including political leaders. Contrary to the expectations, Facebook denied that the published (but not very transparent) "newsworthiness" policy was the reason that a number of Mr. Trump's posts flagged for violation of its community before January 6 standards were not removed. The company explained its decision by revealing that it applied an entirely different and rather vague "cross-check" system. Although Facebook told the FOB that the same rules apply to high-profile accounts as to other "common" accounts, the FOB notes that different procedures may easily lead to different substantial outcomes, contributing to perception of arbitrariness and undue influence of political and commercial interests. Facebook also declined to

53 Oversight Board Decision on Donald Trump's Suspension, p. 32.

54 Under the Oversight Bylaws Facebook may decline to answer the board's questions when it "determines that the information is not reasonably required for decision-making in accordance with the intent of the charter, is not technically feasible to provide, is covered by attorney / client privilege, and/or cannot or should not be provided because of legal, privacy, safety, or data protection restrictions or concerns" (Article 2, Section 2.2.2).

55 Oversight Board Decision on Donald Trump's Suspension, Section 9. The biding part of the decision focuses on the penalty imposed on Mr. Trump.

56 Ibid., p. 35. See Human Rights Council, 2013. This is also in line with major regional systems for the protection of human rights. See e.g. ECtHR, Gunduz v. Turkey, no. 35071/97, Judgment of 4 December 2003, and IACtHR, Perozo et al. v. Venezuela, Judgment of 28 January 2009. 
provide the FOB with information about the suspension of other political leaders' accounts. ${ }^{57}$

Generally, the FOB seems dissatisfied with what it knows about Facebook's approach to moderating high-profile accounts, prompting its recommendation that the company makes much clearer and transparent both the newsworthiness allowance and the cross-check review, and more significantly, to report on "relative error rates and thematic consistency of determinations made through the cross-check process compared with ordinary enforcement procedures". ${ }^{58}$

In its recommendations the FOB also suggests that Facebook must resist pressure from governments to silence their political opposition. This is a response to a long-standing criticism against Facebook, particularly regarding its operations in more authoritarian-leaning states like Russia and India. ${ }^{59}$ Namely, the company declined to tell the FOB whether it had been contacted by political officeholders or their staff regarding $\mathrm{Mr}$. Trump's suspension. This decision reaffirms Facebook's earlier refusal to disclose whether political officials pressured the platform to make content decisions in their favour in another case. ${ }^{60}$ Overall, it shows the company's reluctance to allow the FOB to consider the issue of how powerful political actors influence the platform, which is of concern. The FOB's recommendation emphasizes the importance of careful consideration of political context to which end Facebook ought to devote increased resources, including local resources in circumstances where language and customs require more nuance to content moderation, with a focus on high-influence accounts. This should also serve to ameliorate criticism against Facebook for prioritizing content moderation in the US and Western Europe and devoting much less effort and resources in other parts of the world, especially developing countries. ${ }^{61}$

Finally, Facebook's platform has long been used by influential users in ways that have significant consequences and adverse impact on human rights, with perhaps the most striking example being the use of the

57 Oversight Board Decision on Donald Trump's Suspension, p. 21.

58 Ibid., p. 37.

59 See e.g. Graham, T., 2021, The Facebook Oversight Board's Trump Ban Decision Is About More Than Trump, (https://www.justsecurity.org/75990/the-facebook-oversight-boards-trump-ban-decision-is-about-more-than-trump/, 26. 5. 2021).

60 See Facebook Oversight Board, Case Decision 2021-003-FB-UA, 29 April 2021.

61 See e.g. Domino, J., 2021, Beyond the Coup in Myanmar: The Other De-Platforming We Should Have Been Talking About, (https://www.justsecurity.org/76047/beyondthe-coup-in-myanmar-the-other-de-platforming-we-should-have-been-talkingabout/, 27. 5. 2021). 
platform to stoke violence against the Rohingya in Myanmar. ${ }^{62}$ Such influence goes beyond Facebook's approach to moderation of specific posts and is tied to the way Facebook uses its algorithm to affect visibility of the content on its platform. This question, however, also has a direct impact on the company's profit. Therefore, it is no surprise that Facebook has actively curtailed the FOB's ability to effectively attempt to grapple with the platform's own role in the creation of the circumstances that ultimately led to attacks on Capitol Hill on January 6, 2021. In referring the issue to the FOB, Facebook narrowly focused on Mr. Trump's suspension. It also refused to answer the FOB's questions about "how Facebook's news feed and other features impacted the visibility of Mr. Trump's content", "whether Facebook has researched, or plans to research, those design decisions in relation to the events of January 6, 2021", and "whether account suspension or deletion impacts the ability of advertisers to target the accounts of followers".

Nevertheless, the Board issued a recommendation that Facebook undertake a comprehensive review of its role in these events, including designs and policy choices that allowed for the abuse of its platform. This seems to be an open pushback from the FOB against Facebook, and at the very least signals that the FOB is acting in good faith and that it is prepared to genuinely attempt to hold the platform accountable.

The FOB chose not to supplement its own decision on the appropriate prescribed penalty but referred the issue back to Facebook, which is a reasonable approach at least at this point of the process, though the FOB may not have the opportunity to reassess Facebook's final decision due to the constraints of its bylaws. ${ }^{63}$ Referring the issue back to Facebook also forces the company to grapple with the arbitrariness that seems to be present in its decision-making process when it comes to high-profile accounts, ${ }^{64}$ as the FOB gave Facebook six months to develop a new process, which must be based on the gravity of the violation, and clear, necessary and proportionate.

62 Graham, T., 2021.

63 The Oversight Board Bylaws require an active Facebook account for the user to be able to submit a request to the board (Article 3, Section 1.1), and the request must refer to the removal of specific content from the platform for Facebook policy violations (Article 3, Section 1.1.1). Otherwise, Facebook itself may refer the issue to the board.

64 Contrast Facebook's treatment of Donald Trump's account with a month-long freeze imposed on Venezuelan President, Nicolas Maduro. BBC, 2021, Facebook freezes Maduro's page over Covid claim, (https://www.bbc.com/news/world-latin-america-56551350, 27. 5. 2021). 


\section{Conclusion}

The FOB's almost exclusive reliance on international human rights standards in reaching its decision also shows that the Board is not allowing itself to be constrained by Facebook's community policy. This indicates that over time the FOB may evolve standards that will foster a genuine move towards compliance with international human rights law, depending of course, on how Facebook responds to its decision and recommendations.

This remains to be seen. The Oversight Board Charter includes a number of escape clauses for the company as it provides that Facebook's response will be adapted to their technical and operational feasibility and consistent with a reasonable allocation of Facebook's resources, ${ }^{65}$ and the recommendations are, after all, non-binding. The company's response to the previously issued recommendations has been relatively lacklustre, and even when it commits to action it does not commit to a specific timetable. ${ }^{66}$

In conclusion, the decision on restrictions imposed on Mr. Trump's account, in itself, seems rather uncontroversial. The FOB's increased reliance on international human rights standards is a positive development. The decision also reveals significant issues of lack of transparency, which are not likely to be resolved easily or quickly, and perhaps expecting it would not be reasonable. Facebook unsurprisingly seems reluctant to submit to the FOB's control issues which have a more significant impact on its business model and bottom line. Thus, while it can be said with some certainty that the FOB is approaching this experiment in good faith, only time will tell if the same can be said for the company. At this point it is too early to draw any broad conclusions.

\section{BIBLIOGRAPHY}

1. Benesch, S., 2020, But Facebook's Not a Country: How to Interpret Human Rights Law for Social Media Companies, Yale Journal on Regulation Online Bulletin.

2. Karanicolas, M., 2020, Squaring the Circle Between Freedom of Expression and Platform Law, Journal of Technology Law \& Policy, Vol. 20.

3. Lwin, M., 2020, Applying International Human Rights Law for Use by Facebook, Yale Journal on Regulation Online Bulletin.

65 Article 5 Section 3 of the Oversight Board Charter.

66 Facebook's detailed response to the previous recommendations, (https://about. fb.com/wp-content/uploads/2021/02/OB_First-Decision_Detailed_.pdf, 27. 5. 2021). 
4. Schabas, W. A., 2019, Nowak's CCPR Commentary: U.N. International Covenant on Civil and Political Rights, 3rd rev. ed., Kehl, N. P. Engel Publisher.

\section{Documents}

1. Facebook, Deed of Amendment of the Oversight Board Trust Agreement, 2020.

2. Facebook, Limited Liability Company Agreement of Oversight Board LLC, 2019.

3. Facebook, Oversight Board Bylaws, 2020.

4. Facebook, Oversight Board Charter, 2019.

5. Facebook, Oversight Board Trust Agreement, 2019.

6. Human Rights Committee, General Comment No. 34, UN doc. CCPR/C/GC/34 (12 September 2011).

7. Human Rights Council, Rabat Plan of Action on the prohibition of advocacy of national, racial or religious hatred that constitutes incitement to discrimination, hostility or violence, UN doc. A/HRC/22/17/Add.4 (11 January 2013).

8. Human Rights Council, Report of the Special Rapporteur on the promotion and protection of the right to freedom of opinion and expression, $\mathrm{UN}$ doc. $\mathrm{A} / \mathrm{HRC} / 38 / 35$ (6 April 2018).

9. International Convention on the Elimination of All Forms of Racial Discrimination, adopted 21 December 1965, entered into force 4 January 1969, 660 UNTS 195.

10. International Covenant on Civil and Political Rights, adopted 16 December 1966, entered into force 23 March 1976, 999 UNTS 171.

11. UN Office of the High Commissioner for Human Rights, Guiding Principles on Business and Human Rights: Implementing the United Nations "Protect, Respect and Remedy" Framework, UN doc. HR/PUB/11/4 (2011).

\section{Case Law}

1. ECtHR, Gunduz v. Turkey, no. 35071/97, Judgment of 4 December 2003.

2. Facebook Oversight Board, Case Decision 2021-001-FB-FBR, 5 May 2021.

3. Facebook Oversight Board, Case Decision 2021-003-FB-UA, 29 April 2021.

4. Facebook Oversight Board, Case Decision 2021-005-FB-UA, 28 January 2021.

5. IACtHR, Perozo et al. v. Venezuela, Judgment of 28 January 2009.

\section{INTERNET SOURCES}

1. Domino, J., 2021, Beyond the Coup in Myanmar: The Other De-Platforming We Should Have Been Talking About, (https://www.justsecurity.org/76047/beyondthe-coup-in-myanmar-the-other-de-platforming-we-should-have-been-talkingabout/, 27. 5. 2021). 
2. Facebook Community Standards, (https://www.facebook.com/communitystandards/, 30. 5. 2021).

3. Facebook's Corporate Human Rights Policy, (https://about.fb.com/wp-content/uploads/2021/03/Facebooks-Corporate-Human-Rights-Policy.pdf, 27. 5. 2021).

4. Facebook's response Oversight Boards recommendations, (https://about.fb.com/ wp-content/uploads/2021/02/OB_First-Decision_Detailed_.pdf, 27. 5. 2021).

5. Ghaffary, S., 2020, Facebook's independent oversight board is finally up and running, Vox Recode, (https://www.vox.com/recode/2020/10/22/21528859/facebook-oversight-board-mark-zuckerberg, 30. 5. 2021).

6. Graham, T., 2021, The Facebook Oversight Board's Trump Ban Decision Is About More Than Trump, (https://www.justsecurity.org/75990/the-facebook-oversightboards-trump-ban-decision-is-about-more-than-trump/, 26. 5. 2021).

7. Harris, B., 2019, An Update on Building a Global Oversight Board, Facebook Newsroom, (https://about.fb.com/news/2019/12/oversight-board-update/, 30. 5. 2021).

8. Mark Zuckerberg's announcement on his Facebook account, (https://www.facebook.com/zuck/posts/10112681480907401, 27. 5. 2021).

9. Milanovic, M., 2021, The Facebook Oversight Board Made the Right Call on the Trump Suspension, (https://www.ejiltalk.org/the-facebook-oversight-board-madethe-right-call-on-the-trump-suspension/, 25. 5. 2021).

10. Oversight Board website, (https://oversightboard.com/appeals-process/, 30. 5. 2021).

11. Oversight Board website, update on the appeals procedure, (https://oversightboard.com/news/267806285017646-the-oversight-board-is-accepting-userappeals-to-remove-content-from-facebook-and-instagram/, 30. 5. 2021).

12. Tan, S., Shin, Y., Rindler, D., 2021, How one of America's ugliest days unravelled inside and outside the Capitol, Washington Post, (https://www.washingtonpost. com/nation/interactive/2021/capitol-insurrection-visual-timeline/, 27. 5. 2021).

13. BBC, 2021, Facebook freezes Maduro's page over Covid claim, (https://www.bbc. com/news/world-latin-america-56551350, 27. 5. 2021).

\title{
ODLUKA FEJSBUKOVOG NADZORNOG ODBORA U SLUČAJU TRAJNE SUSPENZIJE NALOGA DONALDA TRAMPA
}

\author{
Ivana Vukčević
}

\section{APSTRAKT}

Fejsbukov Nadzorni odbor („Oversight Board“), telo koje je kompanija formirala kako bi delovalo kao apelacioni mehanizam za Fejsbukovo moderiranje sadržaja, objavio je 5. maja 2021. godine odluku o „suspenziji na neodređeno vreme" naloga bivšeg predsednika Sjedinjenih Američkih Država Donalda Trampa. Fejsbuk je odluku o suspenziji doneo između 6. i 7. januara 2021. godine zbog Trampovih objava u vezi s neredima na 
Kapitol hilu u Vašingtonu. Ovaj komentar analizira odluku Nadzornog odbora i pokazuje njegovo gotovo isključivo oslanjanje na međunarodne standarde ljudskih prava, što je pozitivno. Pored toga, analiza odluke ukazuje na teškoće i potencijalan nedostatak volje Fejsbuka u pogledu formiranja jedinstvenog načina na koji tretira profile političkih lidera, kao i opiranje kompanije da se uhvati u koštac sa načinom na koji je njen poslovni model potencijalno doprineo nasilnim događajima, uključujući i nerede na Kapitol hilu, 6. januara 2021. godine.

Ključne reči: Fejsbuk, Nadzorni odbor, Donald Tramp, sloboda govora, društvene mreže, moderiranje sadržaja, suspenzija na neodređeno vreme, politički lideri, profili velikog uticaja, međunarodno pravo ljudskih prava.

Article History:

Received: 31 May 2021

Accepted: 11 June 2021 